\title{
The Necessity and Violence of Theory
}

\author{
Stephen J. Ball ${ }^{*}$ \\ Institute of Education, University of London, UK
}

Published in Discourse: Studies in the Cultural Politics of Education, 2006, 27 (1), pp. 3-10.

\begin{abstract}
This paper offers a personal view of the need for and uses of theory in educational research. It draws on the work of two exemplary theorists to point up the epistemological role of theory in making research possible and making it reflexive. The second section of the paper deploys some recent ideas and research from class theory and class analysis to suggest some of the limitations of the use of social class in current educational research and some ways of thinking differently about class.
\end{abstract}

\section{Introduction}

Perhaps as educational researchers we need to appreciate better the work that theory does. To this end, I want to say something about some general theoretical influences that are important to me in the way I go about research, and then something more specific and substantive about the role of class theory in educational research. I am seeking here to highlight the very practical role of theory in research as a conceptual toolbox, and means of analysis, and a system of reflexivity.

The two theorists I find most provocative, productive and "useful" both deny and avoid having "a theory" - both are essentially concerned with "practice", the practice of social science and social research, rather than global abstractions for their own sake. They are both thought of as theorists, but they saw themselves as researchers, indeed they are far more concerned about epistemology and its pitfalls than with theory per se, and with understanding how we think about the social as a starting point for thinking differently about the social world, thinking between existing positions, and thinking against mindless orthodoxies. Both sought to break epistemologically with the scientistic mimicry of the social sciences and find a form of research practice unencumbered by the naturalism of what one called "spontaneous sociology" (everyday thinking). They were both critically aware of the ways in which sociology constitutes the object of its theorising. That is, the way in which the positions we take and the concepts we use play their part in making-up our research objects. That we do not have direct and unencumbered access to a social world waiting patiently and passively to be researched

- Stephen J Ball, Karl Mannheim Professor of Sociology of Education, Institute of Education, University of London, 20 Bedford Way, London WC1H-OAL, UK. Email: s.ball@ioe.ac.uk 
and known. They are also both committed to avoiding closure, their work trades in the possibilities of paradox, and they are against making the social more real, more orderly, more predictable than it is. The world as it is, as one put it, is "complicated, confused, impure, uncertain" (Bourdieu, Chamboredon \& Passeron, 1991, p. 259). And they are both angry and critical, both activists and public intellectuals whose work is a form of "critical explanation" and a means to "sap power". All of which confounds the possibilities of conventional versions of intellectual rigour. And, as it happens, they are both French - they are Michel Foucault and Pierre Bourdieu. Their work is very different, but not as different as is sometimes thought. (Foucault was Bourdieu's sponsor to the College de France).

As Foucault explained, his purpose is "not to formulate the global systematic theory which holds everything in place, but to analyse the specificity of mechanisms of power ... to build little by little a strategic knowledge" (Foucault, 1980, p. 145) and, as Bourdieu often urged, he wanted his readers to read his works as "exercise books" rather than theories and was keen to "remind us that 'theory' should not be valued for its own sake" (Karalayali, 2004, p. 352). He felt strongly that we need to be reflexively aware of the implications and effects of theory in relation to the social world we conjure up in our work. He was indeed critical of what he called the "intellectualist bias" which always arises when a researcher is insufficiently critical of the "presuppositions inscribed in the act of thinking about the world" (Bourdieu \& Wacquant, 1992, p. 39) and the failure to grasp "the logic of practice" which stems from this. Indeed part of Bourdieu's endeavour was to destabilise and re-invent the sociological habitus, "a system of dispositions necessary to the constitution of the craft of the sociologist in its universality" (Bourdieu, 1993, p. 271). And importantly, Bourdieu sought to work between binaries rather than be constrained to make false choices between poles - his social model is articulated between objectivism (construction of a discourse within which to converse with other sociologist about the object) and subjectivism, his epistemology is enacted between scientism and theoreticism, which implies that one can grasp reality without "touching it" (Karalayali, 2004, p. 365).

Foucault goes further; in his self awareness and his scepticism about theory and research, he often claimed that his books are fictions, but it is important to understand what he meant by that and how this was part of his own strategic struggle against the traditional disciplines of social science. His books are fictions "only because the power relations and the disciplinary establishments within which they could be validated don't yet exist" (Foucault, 1980, pp. 192-193). In writing outside of the expectations and constraints of intellectualism, his work had no framework of disciplinary evaluation within which it could be judged - and indeed Foucault worked constantly to avoid being captured by and within the disciplines of social science, which he saw as limits to the possibilities of thought.

Am I a Foucauldian then-Clearly no! Am I a Bourdieurian-maybe a failed one! -I do not seek to be anything. I do not want to mimic, or emulate these writers, even if I possibly could. I want to learn from them, I want to be challenged by them and to struggle with the frustrations to certainty that they present. I want to be made uncomfortable and not "let half-truths and or received ideas steer me along" (Said, 1994, p. 17)-perhaps want is the wrong verb, rather I constantly confront discomforts that I cannot ignore.

But I also want to experience and hold on to those moments when I read a line or a paragraph, and it is like the author stretches a hand out from the page towards my own 
hand, and I think yes, I think that too, that expresses something that I have never been able to quite capture into words.

Foucault in particular made an art form out of discomforting his readers and wouldbe emulators. He constantly disavowed and distanced himself from his own work. As noted already he denied any attempt on his part to construct a theoretical system or holistic account on the social. His work is full of discontinuities, diversions and evasions. In style as in substance he sought to work outside and against the conventions of "normal" rigour. Michael Walzer (1988, p. 193) captures and responds to this in an interesting way when he explains that his own rendition of Foucault's critical stance requires that he "adopt a 'constructivist' position".

Since Foucault never presented it [his critical stance] in anything like a systematic fashion, I shall put it together out of the later (and more political) books and interviews, ignoring passages that I don't understand and refusing to live at the heights of his flamboyance.

In other words, quite rightly, Walzer reads Foucault as a "writerly text", as a text which invites the reader to participate in the making of meaning rather than simply be subject to it. Foucault's elusivity creates spaces for the reader and user of his work to be creative and to be adventurous.

In a different sense one of the charms of Bourdieu is that it is possible to see the flaws and discontinuities in his work, as well as its clear evolution over time; although the mis-ordering of his French publications when translated into English does not always make this easy. In his efforts to be absolutely clear about the grounds of his work, he reveals, rather than obscures, as is the case in most social scientific writings, its limits, omissions and inconsistencies. Bourdieu was also very much a pragmatic realist!

All of this is demanding and liberating in equal measure. Bourdieu and Foucault offer a form of social scientific practice and thinking which is not limited to the discursively constructed boxes, categories and divisions of modernist thinking. But taking them and the way in which they work seriously does not involve giving up what we believe or find useful or productive. It does not mean becoming "something", swapping new orthodoxies for old, rather it means struggling against the complacencies and comforts of "being something", of orthodoxy for its own sake". And all of this in turn requires, as Edward Said (1994) argued, "both commitment and risk, boldness and vulnerability" (p. 10), and it means accepting that work is always "unfinished and necessarily imperfect" (p. 17) despite increasingly frenetic demands for definitive statements and firm and conclusive "findings".

It also means giving up on spontaneous empiricism, casual epistemologies, theory by numbers, and constantly struggling against the governmentalities of scientism to find a proper rigour, a thoughtful reflexive and practical rigour-a rigour that goes beyond the niceties and safety of technique to find a form of epistemological practice that is not simply self-regarding.

So I will finish with a very brief attempt to illustrate how these fascinations, discomforts and avoidances play upon and within my work. And I will do that in relation to my very modernist preoccupation with social class, a preoccupation that Bourdieu would have little problem with but one that would be anathema to Foucault. I will draw on some of the influences that played their part in the writing of Class Strategies and the Education Market (Ball, 2003), which both uses and tries to move beyond the existing body of sociological class theory. The book was "written between rather than against" existing work, it differs from rather than opposes, and certainly does not try "to reduce others to silence" (Foucault, 1974, p. 17)2 and it is a strategic, unfinished text. 
What do recent developments in class theory, and more generally Bourdieu's writing on class have to say to and offer to education researchers? Three things perhaps.

1. Certainly in a technical and theoretical sense the class categories used in much educational research seem crude and ineffectual - significant feminist and revisionist critiques of class analysis are ignored, out-moded models of class, and class relations are repeatedly rehearsed, changes in the class structure are unattended to and the complexities of classed families are bracketed away (despite the fact that these have a particular and enduring relevance to educational issues). For the most part, in education research on social class and "in conventional class analyses" families "appear like phantoms, clearly implicated in the intergenerational transmission of social and economic advantage, and yet assuming a unitary status lacking in real social content" (Witz, 1995, p. 45). Generally educational research tends to settle for what is available rather than what is meaningful, often settling for surrogate indicators, like Free School Meals, which have litte sensible relation to class analysis. The complexities of cross-class, and dual-income and trans-national family structures are conveniently avoided, and Rosemary Crompton's warning that "it is not possible to construct a single measure which could successfully capture all the elements going to make up social class - or even structured social inequality" (Crompton, 1998, p. 114) is constantly ignored. Generally the nuances and ambiguities of class positionings are set aside-while as Bourdieu (1987 p. 13) argues "In the reality of the social world, there are no more clear-cut boundaries, no more absolute breaks, than there are in the physical world". Social boundaries, he suggests, can be thought of as "imaginary planes" or a more appropriate image "would be that of a flame whose edges are in constant movement, oscillating around a line or surface" (p. 13). Consequently it is often difficult to read classed individuals as though their experiences were transparent concomitants of the social category they are allocated to. Educational research does this as normal practice. The ontological status of class is not "ready-made in reality" (Wacquant, 1991, p. 57) but is routinely taken to be so.

2. Further, with notable exceptions, developments in class theory, as in the analysis of class fractions (see Vincent, Ball \& Kemp, 2004), debates concerning an under-class, and work on class and space - both in local and global terms, are systematically neglected. Educational research can sometimes be read, in class terms, as though it is stuck in the 1950s. Whereas almost all of the contributors to the class debate emphasise the need to renew class analysis "in the context of current social changes" (Butler, 1995, p. 35). Class analysis works as Crompton (1995, p. 74) argues within "a very fluid and rapidly developing situation", and she goes on to say, "this does not mean we are witnessing the end of class analysis ... Rather ... the best way forward is to explore a more flexible approach". In particular recent work in class theory and class analysis emphasises the interactions of space and social networks in class formation and reproduction. The point is that class is not the same everywhere. It does not mean the same thing in Durham, as it does in Cornwall, as it does in London or Adelaide. Butler (2003) for example, explores what he terms "the Metropolitan Habitus" and Savage, Bagnall and Longhurst (2004) explore four different narratives of middle class life in four different areas of Manchester, which includes differences in the involvement of the research families with their children's education (Bagnall, Longhurst et al. 2003). Class meanings are 
inflected by culture and place. Class identities are "located" and "developed through the networked geography of places articulated together" (Savage, Bagnall \& Longhurst, 2004, p. 208). Or in Bourdieu's words "Social agents, and also things insofar as they are appropriated by them and therefore constituted as properties, are situated in a place in social space ..." (Bourdieu, 1999, p. 134). We know ourselves and relate to others from where we belong, or sometimes out of a sense of not belonging, of feeling out of place. The spaces and places of class exist in several senses which have a particular relevance to education. Schools themselves are classed spaces, within which some students feel at home and others can be distinctly uncomfortable. Education is a trajectory through spaces of learning and our movement through these spaces can be re-affirming of who we are or be part of becoming different, and a process of class dis-identification (see Mahony \& Zmroczek, 1997). What we call social mobility is also typically of form of spatial mobility and exposes those who are mobile to the possibilities of not belonging (see Reay, David et al., 2005) and a variety of joys and sufferings and renunciations. We may even learn to occupy space and move through it differently as our bodily hexis changes to accommodate to what is "strict and sober, discreet and severe" (Bourdieu, 1986a, p. 338) and as we seek stature and substance, and to display a sense of entitlement. The geography of class and education can also be seen at the present point in time in the interplay of parental choice, school admissions criteria and house prices. Classes use and mis-use space differently, sometimes to their advantage, as a resource and sometimes they are 'trapped' within damaging spatial identities. Spatial resources are unevenly distributed, and some can be deployed to ensure access to schools of a certain kind, that is, to those places where there are others "like us". In some circumstances the middle classes are able to colonise schools (Butler et al., 2003) and concomitantly the process of gentrification is inflected by the availability of particular kinds of school places in particular locations. (See Taylor (2002) on the geography of school choice). Indeed the relations of education and social class do not make much sense without a sense of space and place but much educational research which deploys social class categories floats free of such material under-pinnings.

3. Far too little attention is paid to class practices or given to thinking about the meaning of class - what class is. Bourdieu provides cautions and insights in both respects, and the recent work of Mike Savage, Beverley Skeggs, Diane Reay, Tim Butler and Paul Connolly, all influenced by Bourdieu, to a greater or lesser extent, illustrates what can be done with class by moving beyond the "theoreticist illusion" (Bourdieu, 1987 p. 7) of "class on paper" to take seriously how class "gets done". Class "is something that happens (and it can be showed to have happened) in a human relationship" (Thompson, 1980, pp. 8-9). Class is an identity and a lifestyle, and a set of perspectives on the social world and relationships in it, marked by varying degrees of reflexivity. Identities, lifestyles, perspectives and relationships are "constituted in the course of collective history" and "acquired in the course of individual history", which "function in their practical state" (Bourdieu, 1986a, p. 467). Class, in this sense, is productive and reactive. It is an identity based upon modes of being and becoming and forms of distinction that are realised and reproduced in specific social locations as noted already. We "think" and are "thought by" class. It is about being something and not being something else. It is relational. Class is also a trajectory, a path through space and time, a 
"history of transactions" (Walzer, 1984). We are not always the same, or always able to be the same, as the world around us changes. "Real world classes are constantly being constructed around us, people are constantly doing class" (Connell, 1983, p. 148). Our current sense of who we are may be deeply invested in once having been someone different or wanting to be someone else in the future. Similar class positions are held and experienced differently, and have different histories. Class positions and perspectives are produced from and invested with the traces of earlier choices, improvisations and opportunities, as well as being inflected by chance. Transactions are cumulative: "aspects of action and interaction are constantly being negotiated, reformulated, modified" (Devine, 1997, p. 9). Each new choice or point of decision-making is confronted with particular assets or capitals (economic, social and cultural) in hand, to be exchanged or invested; and for an individual or a family volumes of capital may be "increasing, decreasing or stationary" (Bourdieu, 1986a, p. 120). Advantages in the form of capitals can be stored and accumulated for future use (Lee, 1993). In other words, I take class to be dynamic and emergent, as Savage (2000, p. 69) puts it, "people now have to achieve their class positions". As such, reproduction is never guaranteed and mobility, up or down, is always possible. Such mobility is both contingently and strategically dependent. Class and class inequalities need to treated and "understood dynamically" (Savage, 2000, p. 69), as "a longitudinal process rather than a crosssectional one", but without losing a sense of the relative stability of class relations

- stable and static are not the same. All this is about how class is achieved and maintained and enacted rather than something that just is! Class is realised and struggled over in the daily lives of families and institutions, in consumption decisions, as much as in the processes of production, and particularly at moments of "crisis" and contradiction as parents think about the wellbeing and happiness and futures of their offspring. Class is about "knowing" how to act at these defining moments (see Devine, 2004)

\section{Conclusion}

In this paper I have sought to make a case for the urgent necessity for theory in educational research and research training; its crucial role in epistemological decisionmaking; in ensuring the conceptual robustness of conceptual categories; and in providing a method for reflexivity - that is, for understanding the social conditions of the production of knowledge. I also suggested the importance of the violence that theory does, as a reflexive tool within research practice, its role in challenging conservative orthodoxies and closure, parsimony and simplicity - that is the role of theory in retaining some sense of the obduracy and complexity of the social. Much of what passes for educational research is hasty, presumptive and immodest. We constantly over-estimate our grasp on the social world and under-estimate our role in its management. The paper also offered a short and rather loose example of the useful work that theory can do in relation to categories like social class - categories which otherwise lie moribund and unproblematised within research practice. 


\section{References}

Wright-Mills, C. (1963) Power, politics and people: Collected essays, I Horowitz (Ed.). NY:

Ballantine. 
As C. Wright-Mills (1963 p. 12) put it a long time ago: "Fresh perception now involves the capacity to continually unmask and smash the stereotypes of vision and intellect which modern communications [i.e. modern systems of representation] swamp us.".

${ }^{2}$ Furthermore, no closure is sought or claimed, it is intended to be read as a set of statements to be worked on. It was a book written throughout with the firm idea in mind that it would have to be re-written, that another book would follow. Part of the exercise of analysis of class in the book is about "appraising concepts as possibilities for future thinking" (Colebrook, 2000, p. 5) and it is an "exercise in making things intelligible" (Parkin, 1979, p. 115). It seeks, as Bourdieu urges, to develop a set of concepts which are "polymorphic, supple and adaptable, rather than defined, calibrated and used rigidly" (Bourdieu \& Wacquant, 1992, p. 23). 